\title{
Management of Incontinence
}

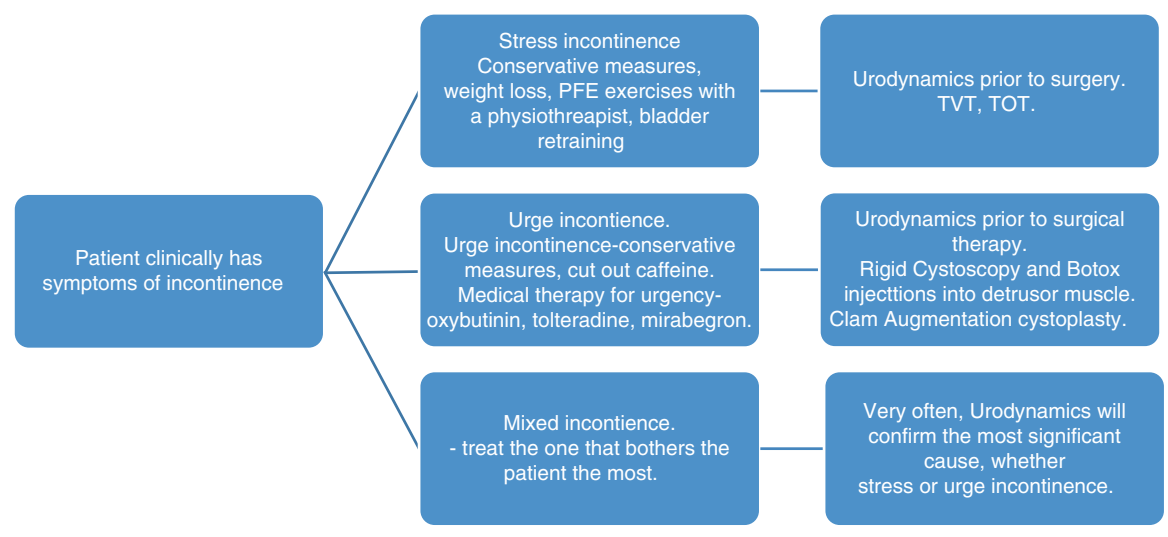

\section{Suggested Reading}

Burkhard FC, Bosch JLHR, Cruz F, Lemack GE, Nambiar AK, Thiruchelvam N, Tubaro A. Guidelines Associates: Ambühl D, Bedretdinova D, Farag F, Lombardo R, Schneider MP. EAU guidelines on urinary incontinence. 2018.

Ellington DR, Erekson EA, Richter HE. Outcomes of surgery for stress urinary incontinence in the older woman. Clin Geriatr Med. 2015;31(4):487-505.

NICE Guidelines CG 171, 2013. 